\title{
DENDROGEOMORPHOLOGICAL EVIDENCE OF FLOOD FREQUENCY CHANGES AND HUMAN ACTIVITIES (PORTAINÉ BASIN, SPANISH PYRENEES)
}

\author{
M. GÉNOVA ${ }^{1 *}$, A. DÍEZ-HERRERO ${ }^{2}$, G. FURDADA ${ }^{3}$, M. GUINAU ${ }^{3}$, and A. VICTORIANO ${ }^{3}$ \\ ${ }^{1}$ Dpto. de Sistemas y Recursos Naturales, Universidad Politécnica de Madrid, Madrid, Spain \\ ${ }^{2}$ Geological Hazards Division, Geological Survey of Spain, Madrid, Spain \\ ${ }^{3}$ RISKNAT Research Group, Geomodels Research Institute, Dpt. de Dinàmica de la Terra i de l'Oceà, Facultat de Ciències \\ de la Terra, Universitat de Barcelona, Barcelona, Spain
}

\begin{abstract}
The Portainé mountain catchment, containing the Port Ainé ski resort (Lleida, Spanish Pyrenees), displays active erosional and depositional phenomena caused by periodic torrential floods. These events present a potential risk and incur significant economic losses. In ungauged remote catchments (like Portainé), trees might be the only paleohydrological source of information regarding past floods. Thus, we estimated the temporal and spatial distribution of torrential floods by dendrogeomorphological techniques to assess whether human impact (land-use changes and infrastructure works) affected their frequency and magnitude. One-hundred and sixty-six samples from 67 trees belonging to 10 different species were analyzed; past flood events of the last 50 years were identified by dating and relating evidence between them. Moreover, a detailed geomorphological study was performed and the available historical data compiled. Our multi-evidence analysis provides new insight into the occurrence of paleofloods. Changes in flood frequency since 2006, especially from 2008, suggest that the geomorphological equilibrium has been disturbed, coinciding with both major earthworks within the ski resort and intense but not extraordinary rainfall. This conclusion has important implications for land planning and the design of future projects in the mountain watersheds.
\end{abstract}

Keywords: dendrogeomorphology, multi-evidence, ungauged mountain basins, flood frequency changes, anthropogenic effects, Pyrenees.

\section{RESUMEN}

La cuenca de montaña de Portainé, donde se sitúa la estación de esquí de Port Ainé (Lleida, Pirineo español), presenta fenómenos erosivos y deposicionales activos debido a periódicas avenidas torrenciales que suponen un riesgo potencial y producen pérdidas económicas significativas. En las cuencas no aforadas remotas, como Portainé, los árboles pueden ser la única fuente de información paleohidrológica y, por ello, en este trabajo se ha estudiado la distribución temporal y espacial de las avenidas torrenciales mediante técnicas dendrogeomorfológicas, evaluando si cambios en los usos del suelo y obras de infraestructura pudieron afectar a su frecuencia y magnitud. Se analizaron ciento sesenta y seis muestras de 67 árboles correspondientes a 10 especies diferentes; y mediante la datación y la relación entre las distintas evidencias, fue posible identificar avenidas pretéritas en los últimos 50 años. Además se realizó un estudio geomorfológico detallado y se recopilaron todos los datos históricos disponibles. Este análisis de evidencias múltiples proporciona una visión nueva sobre la ocurrencia de paleoavenidas, cuyos cambios en la frecuencia ocurridos desde el año 2006, y especialmente desde 2008, sugieren que el equilibrio geomorfológico se vio perturbado, coincidiendo con los movimientos de tierras en las obras de la estación de esquí y unas precipitaciones intensas, pero no extraordinarias. Esta conclusión tiene implicaciones importantes para la planificación territorial y el diseño de obras futuras en las cuencas hidrográficas de montaña.

Palabras clave: dendrogeomorfología, evidencias múltiples, cuenca no aforada, cambios en frecuencia de avenidas, efectos antropogénicos, Pirineos.

*Corresponding author: mar.genova@upm.es 


\section{INTRODUCTION}

Several years ago, Alestalo (1971) coined a new subdiscipline of dendrochronology, i.e. dendrogeomorphology, which applies dendrochronology to date geomorphological elements (e.g. erosion surfaces, glacial moraines and fluvial terraces) and characterize geomorphic processes (e.g. snow avalanches, rockfalls, glacial dynamics and soil erosion). Before this, researchers had already used treering sequences for flood analysis (Sigafoos 1964; Harrison and Ried 1967). A number of studies to date have applied dendrochronology to study flood frequency and magnitude (Ballesteros-Cánovas et al. 2015a; Benito and Díez-Herrero 2015), with most of these assessing natural flood hazards for risk mitigation (Stoffel et al. 2010) and the effects of climate change on fluvial systems (BallesterosCánovas et al. 2015b; Büntgen et al. 2017).

There are very few dendrogeomorphological studies investigating the effects of human impact on flood regimes. Some studies have analyzed the effects of river-regulating dams (St. George and Nielsen 2003), land-use changes linked to forest fires in a catchment (Brown and Sieg 1996), logging (Kochel et al. 2016) and in-channel structural defensive measures (Ballesteros-Canovas et al. 2016). Currently, studies exploring the effects of land-use changes on flood regimes in mountain areas (e.g. ski resorts; Stoffel et al. 2016) are scarce. Furthermore, trees might be the only source of information on past flooding in some ungauged remote mountain basins. Indeed, most dendrogeomorphological studies have been carried out in specially selected areas containing a large number of disturbed riverbank or in-channel trees, with many of these investigations sampling and analyzing at least 30 trees (often about 100) to get a statistically representative population, i.e. tens to hundreds of types of flood dendrogeomorphological evidence (FDEs; Díez-Herrero et al. 2013a). A large proportion of the studies have only used a single species (mostly coniferous), although a few have assessed two or three species that are known to produce a clear tree-ring response to floods (Grissino-Mayer 1993). Regarding mountain catchments, given the lack or scarcity of instrumental and documentary data, dendrogeomorphological research should aim to make the most of all the river reaches, including areas with few trees and different species.

For the above reasons and to obtain new insight into the use of dendrogeomorphological techniques in mountain areas, the aims of the study were: (i) work in a small catchment containing a small number of trees of a large range of species with few documentary records and few instrumental data, a common scenario in mountain river basins; (ii) date different types of FDE and jointly analyze them to obtain reliable results; and (iii) correlate flood regime changes of a mountain river, likely triggered by anthropogenic land-use changes, to dendrogeomorphological results by combining all available studies and data, checking if the dendrogeomorphology captures such changes.

\section{STUDY AREA AND ISSUES}

This study was carried out in the northwarddraining Portainé basin $\left(5.72 \mathrm{~km}^{2}\right)$ (Eastern Pyrenees, Spain). The maximum and minimum elevations are $2439 \mathrm{~m}$ a.s.l. at Orri peak and $950 \mathrm{~m}$ a.s.l. at the confluence with the Romadriu River, respectively. The Port Ainé ski resort, located at the headwaters, opened in 1986 and is an important economic infrastructure of this mountain region. Its access road was built between 1970 and 1995 and traverses the streams several times (Figure 1c).

The area shows abrupt relief. All the outcropping materials are highly erodible and can give rise to sediment-laden flows. The bedrock consists of highly folded and fractured Cambro-Ordovician metapelites and sandstones (Hartevelt 1969; Ortuño et al. 2017). Geomorphologically, the basin can be divided into two large sectors (IGC 2013a): a southern gentler one $\left(10^{\circ}-20^{\circ}\right.$ slope $)$ covered by pastures and a northern steeper one $\left(25^{\circ}-35^{\circ}\right.$ slope) that is densely forested. Unconsolidated colluvial deposits (often $>10 \mathrm{~m}$ thick) cover the slopes smoothing their relief, whereas torrential deposits are found in the valley bottoms. The climate is Alpine Mediterranean (mean annual rainfall is 800 $\mathrm{mm}$ and mean annual temperature $5-7^{\circ} \mathrm{C}$ ).

Although there has been only one meteorological station within the basin since August 2011 (at $1985 \mathrm{~m}$ a.s.l.), it is well known that torrential events are mostly related to intense and localized convective summer rainstorms (ICC and Meteocat 


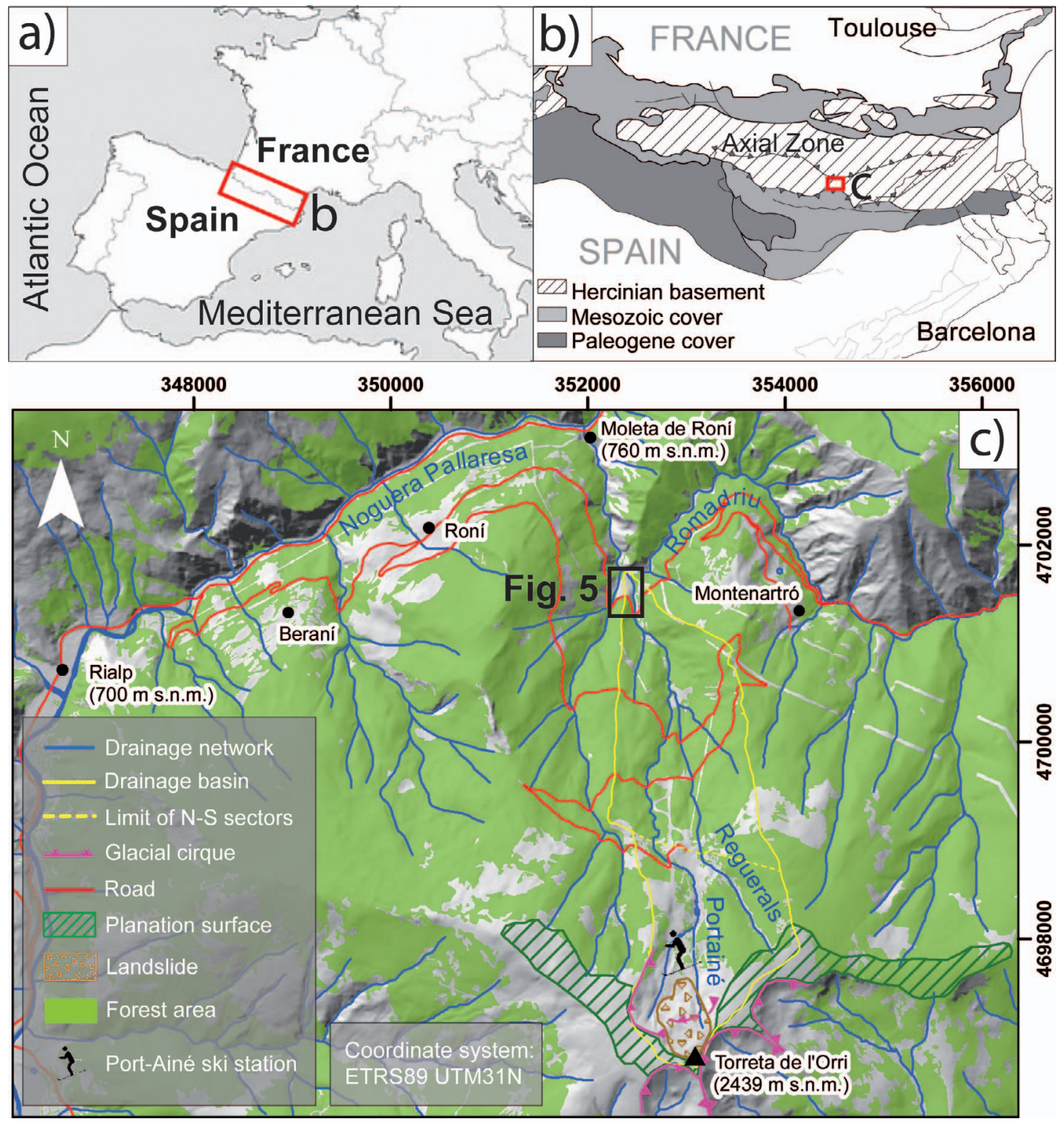

Figure 1. Location of the study area. (a) Geographic location of the Pyrenees; (b) Geological setting in the Axial Zone of the Pyrenees; (c) Geomorphological setting and delineation of the Portainé drainage basin, with the study area indicated by a black square. This black square corresponds to the study area in Figure 5.

2008; see the Results section), whose distribution is strongly affected by orography. There are no flow gauging stations.

In the Portainé basin, ten torrential flows have occurred since 2006 (Furdada et al. 2016). Especially since the extraordinary event of September 2008 , these events affect the roads, causing signifi- cant damage and economic costs of up to 6,300,000 $€$ (Pinyol et al. 2017). Since 2009, 15 sediment retention barriers have been installed along the channels to reduce the impact of the torrential flows (Fañanás et al. 2009). However, these flows still occur almost every year, involving large geomorphic changes and affecting the road (Victoriano et al. 


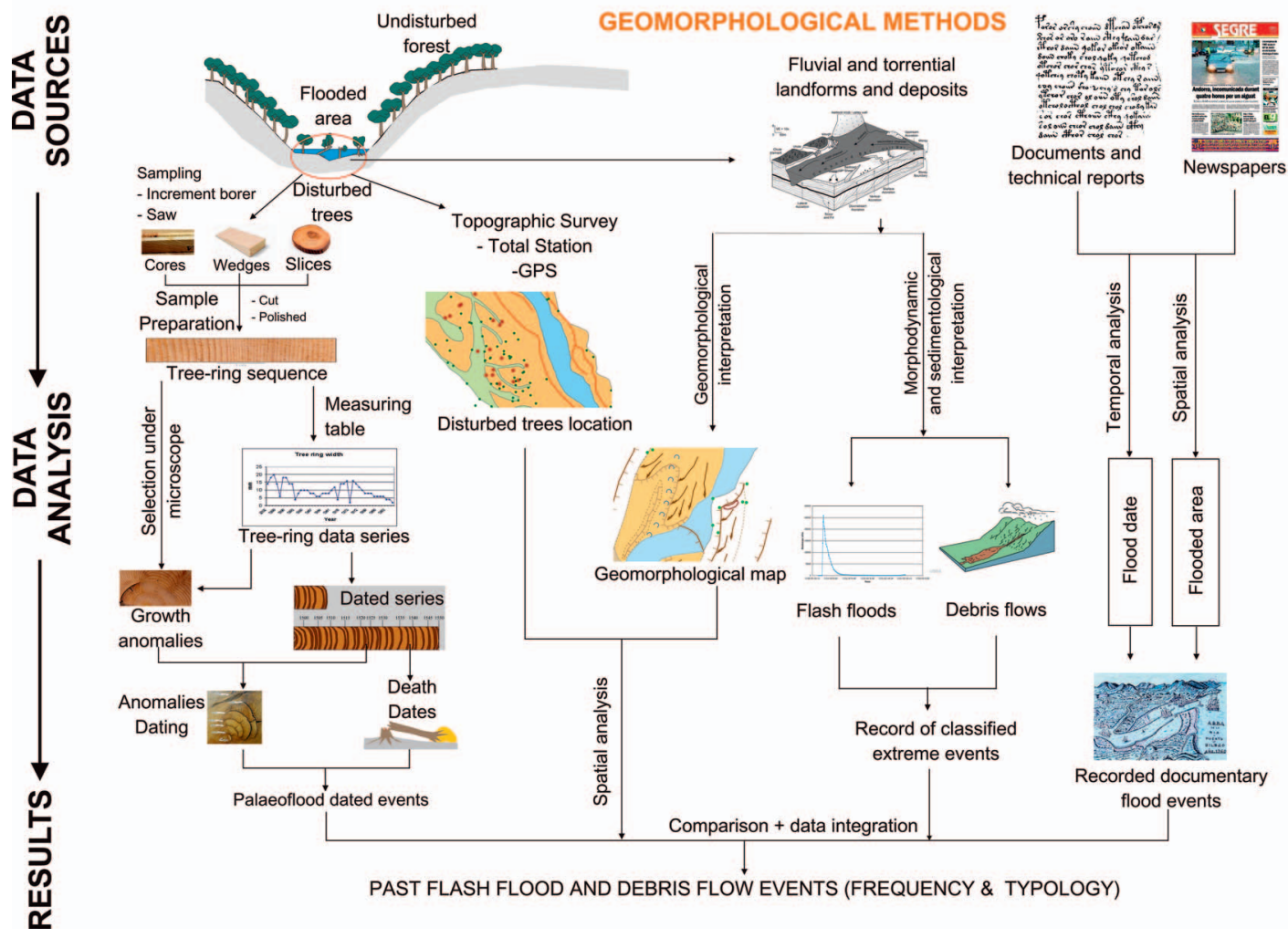

Figure 2. General diagram of the main methodological procedures used in this study (adapted from Genova et al. (2015b) and Benito and Díez-Herrero (2015)).

2016). Their effect on the lower part of the Portainé stream is seldom recorded.

The present dendrogeomorphological study was carried out in this most downstream stretch, in the elongated alluvial debris cone formed at the confluence with the Romadriu River. The cone, covering an area of about $4850 \mathrm{~m}^{2}$, is limited by an abrupt slope on the right (eastward). On the left (westward), a spreading lobular deposit displays distributary channels and consists of heterometric blocks and gravels. The cone harbors a broadleaf forest that shows great diversity in the tree species, which contains (Populus tremula L., Populus nigra L., Fraxinus excelsior L., Prunus avium L., Quercus petraea (Matt.) Liebl., Tilia platyphyllos Scop., Juglans regia L., Acer campestre L., Salix caprea L. and Betula pendula Roth). The trees are located outside the main channel. As they act as an obstacle to the flow, high-discharge events lead to the upstream accumulations of boulders, cobbles, gravel and the trunks of dead and transported trees.

\section{DATA ACQUISITION AND METHODS}

The general methodology used in this study is schematized in Figure 2.

\section{Dendrogeomorphological Methods}

One-week field surveys were undertaken in March 2014 and in March and September 2015 in the Portainé alluvial cone. During the field surveys, all the trees showing damage, most probably caused by the impact of boulders and/or large pieces of wood during torrential events, were sampled using dendrogeomorphological methods (Stoffel and Bollschweiler 2008; Díez-Herrero et al. 2013a; 


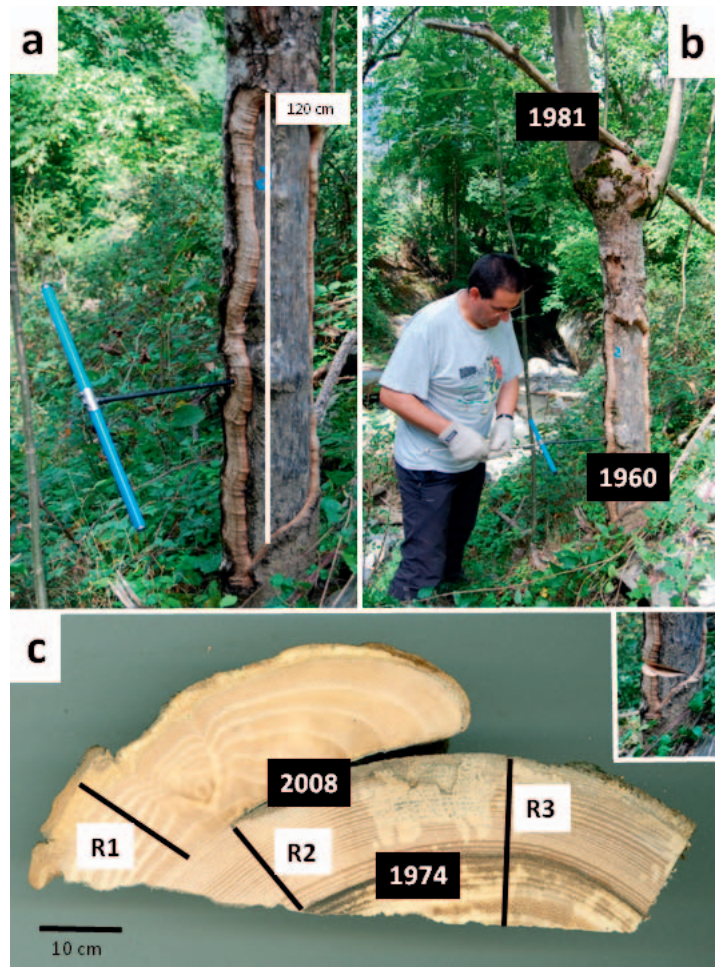

Figure 3. Dendrochronological sampling and the studied wedge of the PA68 tree (Fraxinus excelsior). (a) and (b) Sampling using a Pressler increment borer, with the inner-ring dating of the main stem and replacement branch shown in (b). (c) Transverse section of the wedge showing the radii measured (R1, R2 and R3) and the dating of the internal (1974) and external (2008) scars, the latter partially covered by a callus.

Stoffel and Corona 2014; Génova et al. 2015a). Most of the trees occur on the west deposits of the alluvial cone, with others occurring in different geomorphic positions such as in gravel bars, boulder levees and lobes, or inside the distributary channels of the cone (Victoriano et al. 2018). The main identified macroscopic indicators were scars, decapitations or loss of the main stem, tilting, stem burial and dead trees (Figure 3). Some neighboring trees were sampled, even if they did not show apparent external evidence of damage (Génova et al. 2015a), as they could have contained internal FDE.

For each selected tree, all the necessary data to complete a previously designed inventory sheet were collected, photographs were taken and detailed sketches were drawn. All this information was compiled in a dendrogeomorphological database and inserted into a GIS environment (ArcGIS 10.3), which enabled the study of the geomorphological setting of the sampled trees (Victoriano et al. 2018).

Sampling mainly consisted of extracting cores using a standard Pressler increment borer that was 400-mm long and had an internal diameter of 5 $\mathrm{mm}$. A minimum number of two (as complete as possible) samples were acquired per tree, one in the flow direction and the other in the perpendicular direction. Additional samples were extracted from the scar or callus areas of the injured trees (Stoffel and Bollschweiler 2008) and/or the replacement branch of the decapitated trees (Figure 3). Moreover, some wedges with parts of the callus and complete stem sections were also obtained from heavily damaged or dead trees.

The cores were placed inside a wooden holder for conservation. Once the samples were dried, they were cut or sanded on the transverse section. During this stage of the study, samples from 10 trees were rejected because of rotten cores or indistinguishable rings (including samples from three Betula pendula trees). The remaining samples from 57 trees belonging to nine species that differed in their wood type and pore features (Schweingruber 1990) were analyzed. The LINTAB table and the associated TSAPWin software were used to measure the tree rings (Rinn 2003). Tree-ring series were crossdated using classical methods that included visual, graphic and statistical techniques (Cook and Kairiukstis 1990) and checked using the Cofecha software (Grissino-Mayer 2001). We first crossdated and averaged the tree-ring series of each tree, and afterwards we crossdated the tree-ring series among different individuals that belong to the same species. We then selected and analyzed the FDEs that could provide information about torrential floods (e.g. Shroder 1980; Stoffel and Bollschweiler 2008; Díez-Herrero et al. 2013a; Ruiz-Villanueva et al. 2013; Stoffel and Corona 2014) to investigate the following:

(1) Estimated age to date the establishment of the trees.

(2) Callus and internal scars characterized by unstructured tissues.

(3) Decapitation. One or more branches replace the former stem that has been partially lost (especially caused by destructive floods) to recover the main growth axis. 
(4) Asymmetries in the tree-ring series. The unilateral pressure induced by the material being transported by the flow can lead to a tilting of the stem axis. Broadleaf trees try to compensate for this by forming reaction wood on the side opposite to the direction of the tilting (tension wood). This eccentric growth becomes apparent in the tree-ring series.

(5) Abrupt growth changes. Growth release could result from reduced competition because of the disappearance of neighboring trees during flooding or from the nutrient-rich material and water deposited by the flow. By contrast, growth suppression or the formation of narrower rings could be a consequence of injury or partial stem burial by deposited sediments. Growth suppression also occurs when trees are decapitated or tilted.

Tree age was estimated by determining the maximum number of rings. Most of the samples reached the pith and therefore, further adjustments were not necessary. Dating of the callus and internal injuries provided direct information on the occurrence of the events, whereas the remaining FDEs were used as complementary data. The decapitation date was estimated using a set of different data, i.e. the date of the inner ring of the replacement branch, the age of the scars or growth suppressions in the decapitated trees, as well as their geomorphological position, and the decapitation height.

Both asymmetries and abrupt growth changes (suppressions and releases) in trees are responses to different possible factors. Therefore, they were only used when they correlated with other data and affected more than $10 \%$ of the trees. We also took into account the fact that these types of damage responses tend to develop later than the trigger event (Stoffel et al. 2010). These indicators were analyzed using the LRM software (List Ring Measurement; Holmes 1999), which identifies the most significant years according to their representativeness in different tree groups. Additionally, the death date of some trees was also used to estimate highmagnitude floods. FDE does not indicate whether the event that damaged the trees occurred during the tree-ring formation or in the months since the end of the formation of the previous ring, i.e. during the dormancy period. For this reason, we used biannual denomination for dating the event, referring to it as the Dendrogeomorphological Year (DY). This way of dating events, which has not previously been used and has considerable biological significance, enables a better interpretation of tree responses to an event.

\section{Geomorphological and Documentary Methods}

Detailed tachymetric surveys were performed using a Leica TC1700 total station. Geomorphic forms (e.g. functional and distributary channels, gravel and boulder bars) and numerous trees were mapped. To georeference the obtained dataset point, absolute coordinates of some control points were accurately measured using differential RTK GPS (Khazaradze et al. 2016). A complete geomorphological map was prepared using ArcGIS 10.3. On this map, trees and FDE could be spatially related to one another and with their geomorphological positions (Victoriano et al. 2018).

Documentary data about recent flows and human activities were mostly obtained from different technical reports. Historical data about major past rainfalls and floods were obtained from local eyewitnesses, archives, and newspaper libraries. All the used data sources are cited in Table 3. The flood databases PREDIFLOOD and GAMA, handled and managed by M. Barriendos and C. Llasat (UB), respectively, were also consulted. Pictures provided by the company that manages the hydroelectric power station located at the confluence with the Romadriu River (OPICE S.A.) helped us to analyze the dynamics of the torrential flows of 2008 and 2010 (García-Oteyza et al. 2015).

\section{RESULTS}

\section{Dating Flood Dendrogeomorphological Evidence (FDE)}

The large diversity of the taxa used in this study is representative of the deciduous broadleaf forest that presently characterizes the downstream reach of the Portainé stream and most of the rivers in the Pyrenees, as well as those of other mountain temperate zones. A total of 166 samples from 67 trees belonging to 10 different species were collected and 57 trees from 9 species were used for dating 364 FDEs. The different species displayed 
Table 1. Estimated ages of analyzed species. $\mathrm{PF}=$ pores features; R-p = Ring-porous; Sr-p/R-p = Semi-ring- to ring-porous; Sr-p $=$ Semi-ring-porous; $\mathrm{D}$-p/sr-p = Diffuse- to semi-ring-porous; $\mathrm{D}$ $\mathrm{p}=$ Diffuse-porous). $\mathrm{N}=$ number of trees; $\mathrm{A}_{\max }=$ maximum age; $\mathrm{Fy}=$ first year; $\mathrm{A}_{\mathrm{av}}=$ average age; $\mathrm{sd}=$ standard deviation.

\begin{tabular}{lllrccc}
\hline \multicolumn{1}{c}{ Species } & ID & \multicolumn{1}{c}{$\mathrm{PF}$} & $\mathrm{N}$ & $\mathrm{A}_{\max }$ & $\mathrm{Fy}$ & $\mathrm{A}_{\mathrm{av}} \pm \mathrm{sd}$ \\
\hline Fraxinus excelsior & FE & R-p & 13 & 60 & 1956 & $51 \pm 8.2$ \\
Populus tremula & PT & Sr-p & 15 & 59 & 1957 & $51 \pm 5.7$ \\
Populus nigra & PN & Sr-p & 13 & 56 & 1960 & $46 \pm 8.2$ \\
Prunus avium & PA & Sr-p/R-p & 5 & 48 & 1968 & $43 \pm 4.6$ \\
Salix caprea & SC & D-p/Sr-p & 1 & 47 & 1969 & 47 \\
Acer campestre & AC & D-p & 1 & 42 & 1974 & 42 \\
Juglans regia & JR & D-p/Sr-p & 3 & 86 & 1930 & $79 \pm 10.6$ \\
Tilia platyphyllos & TP & D-p & 3 & 81 & 1935 & $63 \pm 19.6$ \\
Quercus petraea & QP & R-p & 3 & 78 & 1938 & $64 \pm 12.9$ \\
Total/Mean & & & 57 & 86 & & $52 \pm 11.1$ \\
\hline
\end{tabular}

great diversity in their wood type and pore features (Table 1). Some showed macroscopically distinguishable growth rings (ring-porous: Fraxinus excelsior and Quercus petraea), whereas in some other cases, the rings were not so evident (diffuse-porous: Acer campestre, Betula pendula and Tilia platyphyl$l o s)$. Furthermore, there were also others with intermediate features (Juglans regia, Populus nigra, Populus tremula, Prunus avium and Salix caprea). All the sampled trees were located close to the channel or spread along the cone.

\section{Tree Species Ages}

The most common species in the studied broadleaf forest are Populus tremula, Populus nigra and Fraxinus excelsior, which were also the most sampled: 15, 13 and 13 trees, respectively. The maximum and average ages of the sampled trees of these three taxa, as well as those of Prunus avium and the unique trees of Salix caprea and Acer campestre, were similar (Table 1). Therefore, the approximate germination ages of these species were similar and the establishment of these trees would have started in the 1950s. Juglans regia, Quercus petraea and Tilia platyphyllos, which have higher and similar maximum ages, would have established almost 20 years before the other species.

\section{Scar Evidence}

Forty-one scars were dated, which corresponded to 10 different events in the Portainé stream. The external scars were dated to the time marking the beginning of the formation of the unstructured callus tissues. The callus was especially well-defined, which enabled accurate dating of the sections and wedges (Figure 3). In addition, more than ten internal scars were analyzed from the extracted cores. Two internal and two external scars that were almost closed were all dated to A.D. 2000, so it took $c a$. 14-15 years to close those wounds.

\section{Decapitation Evidence}

Decapitation, which involves the formation of replacement branches, was analyzed in 10 trees (7 Fraxinus excelsior, 1 Quercus petraea, 1 Tilia platyphyllos and 1 Salix caprea). To estimate the DY event that decapitated these trees, which occurred prior to the formation of the replacement branches (but we cannot know how many years before), the inner-ring dating of the replacement branch was studied in relation to other data, such as the geomorphological setting of the trees. Most of the decapitated trees occurred in the same area of the downstream stretch of the Portainé stream and in the same geomorphological position. This indicates that the decapitations were produced by flows with similar energies. Furthermore, the heights of the decapitation nodes were very similar (Table 2, Figure 5). Therefore, we inferred that two single events probably caused many of the decapitations. The growth suppressions and the ages of the scars identified in the main stems of the decapitated trees provided additional information. Considering all this evidence, the event that decapitated most of the trees was estimated to have occurred in the 19691970 DY, given that the formation of the oldest replacement branches started in the 1970 vegetative period and the suppressions occurred widely in the 1971 vegetative period. In the same way, another event that affected two other decapitated trees located in different geomorphological positions was determined to have occurred in the 1973-1974 DY.

\section{Other Complementary Evidence}

Asymmetries were detected in $68 \%$ of the tree-ring series. Moreover, suppressions and releases were very frequently found in almost all the trees analyzed. However, as stated in the 
Table 2. Characteristics of the decapitated trees. GP = Geomorphological Position; $H=$ Height of decapitation node; $\mathrm{Ir} T=$ dating of inner ring of trunk; Ir RB = dating of inner ring of replacement branch; $\mathrm{Sc} / \mathrm{Su}=$ scars/suppressions; $\mathrm{E}=$ date of the possible event. * indicates that this value is not determined because the inner part of the trunk was rotten. In the PA35 tree, the estimated Dendrogeomorphological Year of the event that caused the decapitation is not as reliable because of the lack of relation with other evidence.

\begin{tabular}{|c|c|c|c|c|c|c|}
\hline ID Species/ ID Tree & GP & $\mathrm{H}(\mathrm{m})$ & $\operatorname{Ir} \mathrm{T}$ & $\operatorname{Ir} \mathrm{RB}$ & $\mathrm{Sc} / \mathrm{Su}$ & $\mathrm{E}$ \\
\hline FE/ PA26 & Upper deposits of cone & 0.40 & $*$ & 1972 & $-1-$ & $1969-1970$ \\
\hline $\mathrm{FE} / \mathrm{PA} 27$ & Upper deposits of cone & 0.64 & 1968 & 1970 & $-/ 1971$ & 1969-1970 \\
\hline FE/ PA29 & Upper deposits of cone & 0.70 & 1962 & 19731975 & $-/ 1971$ & $1969-1970$ \\
\hline FE/ PA30 & Upper deposits of cone & 0.96 & 1958 & 1974 & $-/ 1971$ & 1969-1970 \\
\hline FE/ PA31 & Upper deposits of cone & 0.88 & 1962 & 1975 & $-/ 1971$ & $1969-1970$ \\
\hline QP/ PA32 & Main inactive channel of cone & 0.74 & 1955 & 1976 & $-/ 1971$ & $1969-1970$ \\
\hline FE/ PA33 & Upper deposits of cone & 0.85 & 1963 & 1978 & $-/ 1971$ & 1969-1970 \\
\hline $\mathrm{SC} / \mathrm{PA} 35$ & Artificial levee & 0.97 & - & 19691970 & $-1-$ & 1969-1970? \\
\hline TC/ PA42 & Terrace & 1.13 & 1951 & 1977 & $-/ 1975$ & 1973-1974 \\
\hline FE/ PA68 & Right-side slope & 1.53 & 1960 & 1981 & $1974 / 1975$ & $1973-1974$ \\
\hline
\end{tabular}

Methods section, these growth anomalies were used as complementary data to date events (Table 3). Table 3 also shows the estimated DY of the death of some trees caused by the burial of the base of their trunks or significant injuries. However, we can only hypothesize which event caused these anomalies.

Table 3 also presents the obtained documentary data of past events directly related to the Portainé catchment (local torrential events), as well as other documentary data (regional rainfalls and floods) and information on human activities.

\section{Temporal and Spatial Reconstruction of Paleo- flood Records}

The 364 FDEs dated in this study are shown in Table 3 and Figure 4, ordered by damage or the type of growth anomaly. Ten DYs were defined by the temporal overlaps of many FDEs: 19691970 ; 1973-1974; 1976-1977; 1982-1983; 19921993; 1997-1998; 1999-2000; 2005-2006; 20072008 and 2009-2010 (Table 3, Figure 4). At least one scar was dated to most of these DYs, except for 1969-1970 and 1982-1983. These two DYs were included in the group of 10 well-defined DYs because a high number of the FDEs analyzed were dated to these years. For example, suppressions found in $43 \%$ of the analyzed trees were dated to 1982 1983. The event-to-event intervals between 19691970 and 2009-2010 are shown in Figure 4b. The average recurrence interval was 4.5 years and the median 4 years. If other events with less evidence were considered (1972-1973 and 1987-1988), the average recurrence interval was 3.6 years and the median 3 years. Other possible prior events, estimated to have occurred in 1956-1957, 1960-1961 and 1964-1965, had similar values (4.4 and 5 years, respectively), but could not be considered because of the scarcity of FDEs.

The data available on extraordinary regional and local rainfalls and debris events (Table 3) show that, in general, a maximum of one major event occurs in one year. However, in some cases, especially since 2008, more than one well-documented local event has occurred in the same DY. Overall, between 2008 and 2015, the average recurrence interval of local events was almost 1 year.

Figure 5 shows the spatial distribution of the FDEs for each DY, indicating the magnitude of the event. Most maps reveal that the FDEs associated with each torrential event have a nearly uniform distribution along the studied stretch. However, some maps (i.e. those for 1976-1977, 19971998 and 2009-2010) show a relatively significant concentration of FDEs in the lower part of the cone. Although there is no strong correlation between the number of FDEs and the surface extension of the events, both of these were the highest for the 1997-1998 DY. The highest number of scars was associated with the 2008-1909 DY, representing a high magnitude event, whereas the decapitations generated by the 1969-1970 event were mostly in the distal area of the alluvial cone. 
Table 3. Synthesis of the main dendrogeomorphological and documentary evidence related to the Portainé stream. Year $=$ year of the dated Flood Dendrogeomorphological Evidence; FDE = Type of Flood Dendrogeomorphological Evidence; DY = Dendrogeomorphological Year (the most reliable highlighted in bold); $\mathrm{N}_{1}=$ total number of dated evidence; $\mathrm{N}_{2}=$ number of evidence corresponding to each DY; human activities highlighted in gray; ? = doubtful dating or unknown exact date. References: $1=\mathrm{Ba}-$ lasch et al. (2008); 2 = Protección Civil [on line]; $3=\mathrm{La}$ Vanguardia [on line]; $4=\mathrm{El}$ Mundo [on line]; $5=\mathrm{ABC}$ [on line]; $6=$ Meteorological Service of Catalonia [on line]; 7 = IGC2008, 2010a, 2010b, 2011, 2013a, 2013b) and IGC et al. (2013); $8=$ Mr. C. Fañanás county administration forest engineer (pers. com.); $9=$ Mr. Tachó eyewitness (pers. com.); $10=$ Mr. J. Montserrat eyewitness (pers. com.); $11=$ Arxiu Comarcal del Pallars Sobirà [on line].

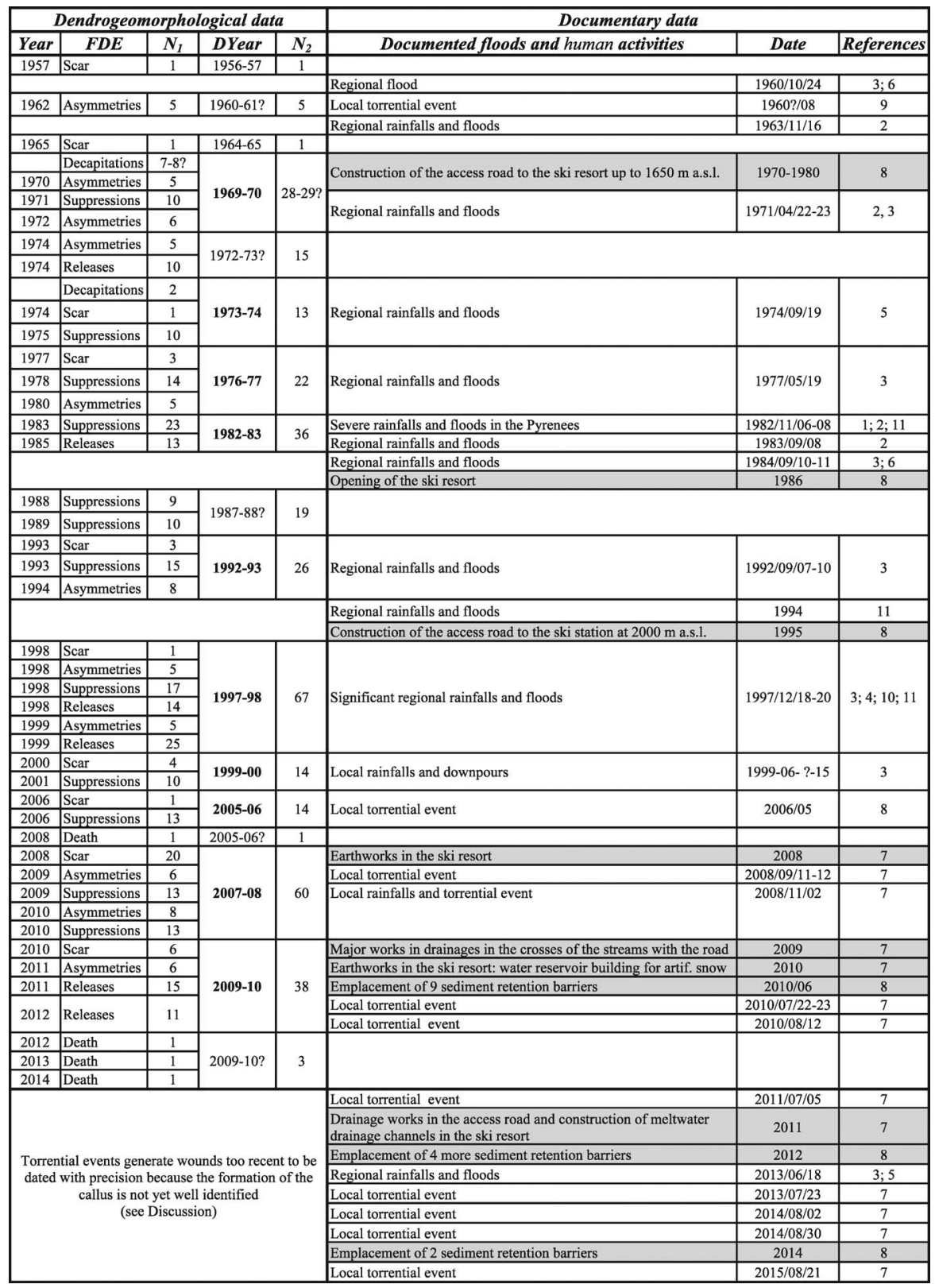



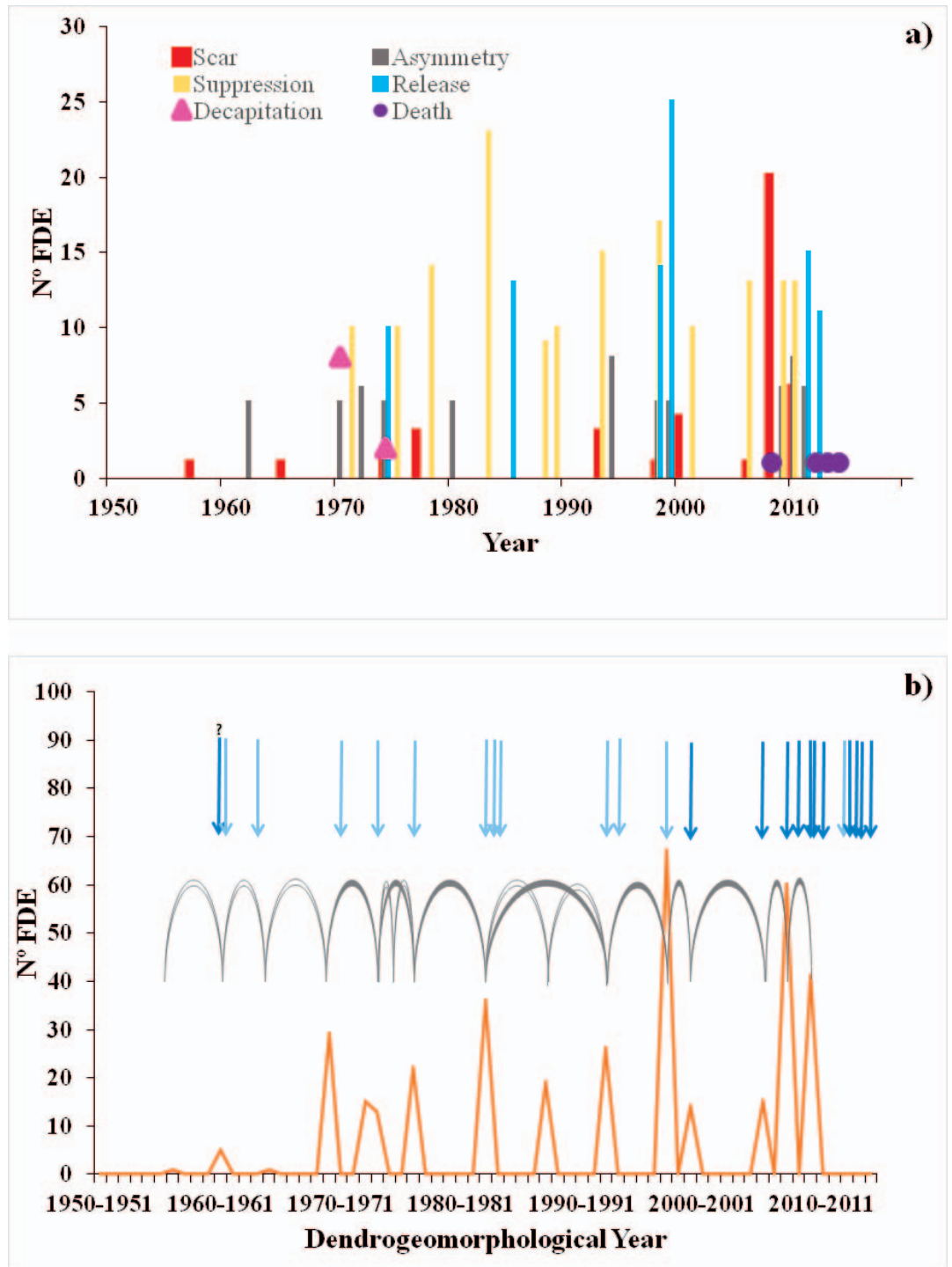

Figure 4. (a) Number of each type of dated Flood Dendrogeomorphological Evidence. (b) Total number of Flood Dendrogeomorphological Evidence (orange), the event-to-event intervals determined in well-defined Dendrogeomorphological Years (solid color arcs) and other intervals determined for events with less evidence (empty arcs), as well as documented events of regional (light blue arrows) or local (dark blue arrows) rainfall in the Portainé stream.

\section{DISCUSSION}

\section{New Multispecies Contribution to Dendrogeomor- phological Analysis}

Some of the species studied have rarely or never been used for dendrochronological or dendrogeomorphological studies, such as Acer campestre, Prunus avium, Juglans regia, Salix caprea or Tilia platyphyllos. Others, like Populus tremula or Populus nigra and especially Fraxinus excelsior and Quercus petraea, have been used more frequently (i.e. Astrade and Begin 1997; Arbellay et al. 2010, 2012; Bollschweiler et al. 2011; BallesterosCánovas et al. 2015a). The use of these species is a new step in hydrogeomorphological studies and broadens the group of species that can be used to assess hydrogeomorphic hazards. In addition, the high number of deciduous broadleaf species 

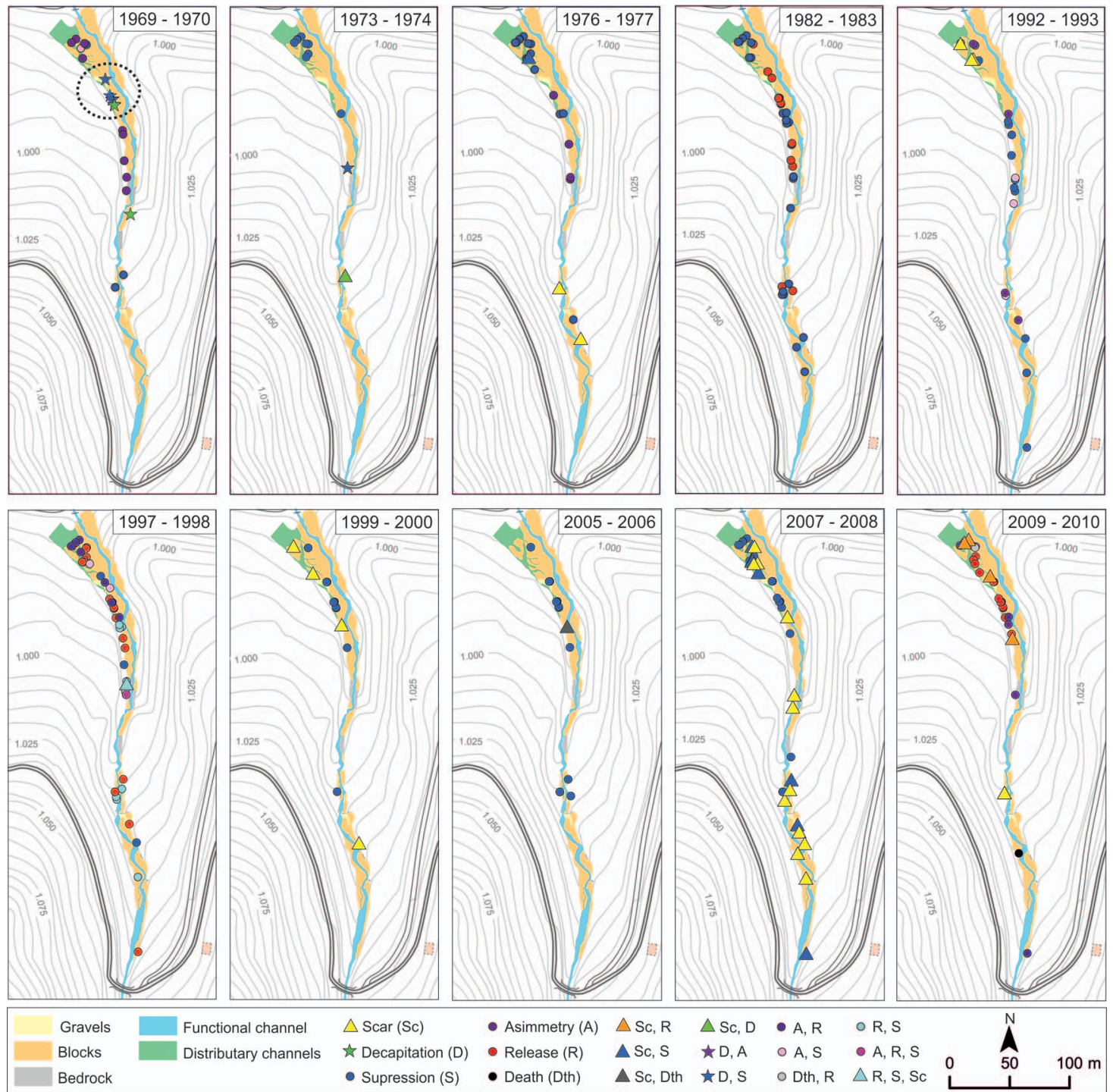

Figure 5. Flood Dendrogeomorphological Evidence distribution in each of the 10 events determined with high reliability. In the 1969 1970 map, dotted circles indicate the area with a significant concentration of stem decapitations.

investigated in this study (9) is in contrast to the other studies in the literature analyzing only 1 to 3 different species for the dendrochronological study of floods (Figure 6).

\section{New Multi-Evidence Contribution to Dendrogeo- morphological Analysis}

FDEs from trees damaged by torrential floods in the Portainé stream were analyzed, as in previous studies from around the world (see compilations in Díez-Herrero et al. 2013b; Ballesteros-Cánovas et al. 2015a; Benito and Díez-Herrero 2015).

The interpretation of FDEs is subject to uncertainties and mismatches because of the limitations of the method. For example, there is no direct correlation between the dates of the largest floods and the type and/or number of dendrogeomorphological pieces of evidence, especially as we go back in time (see the next section). This is merely an indicative approximation because the time it takes to close a wound depends greatly on the 


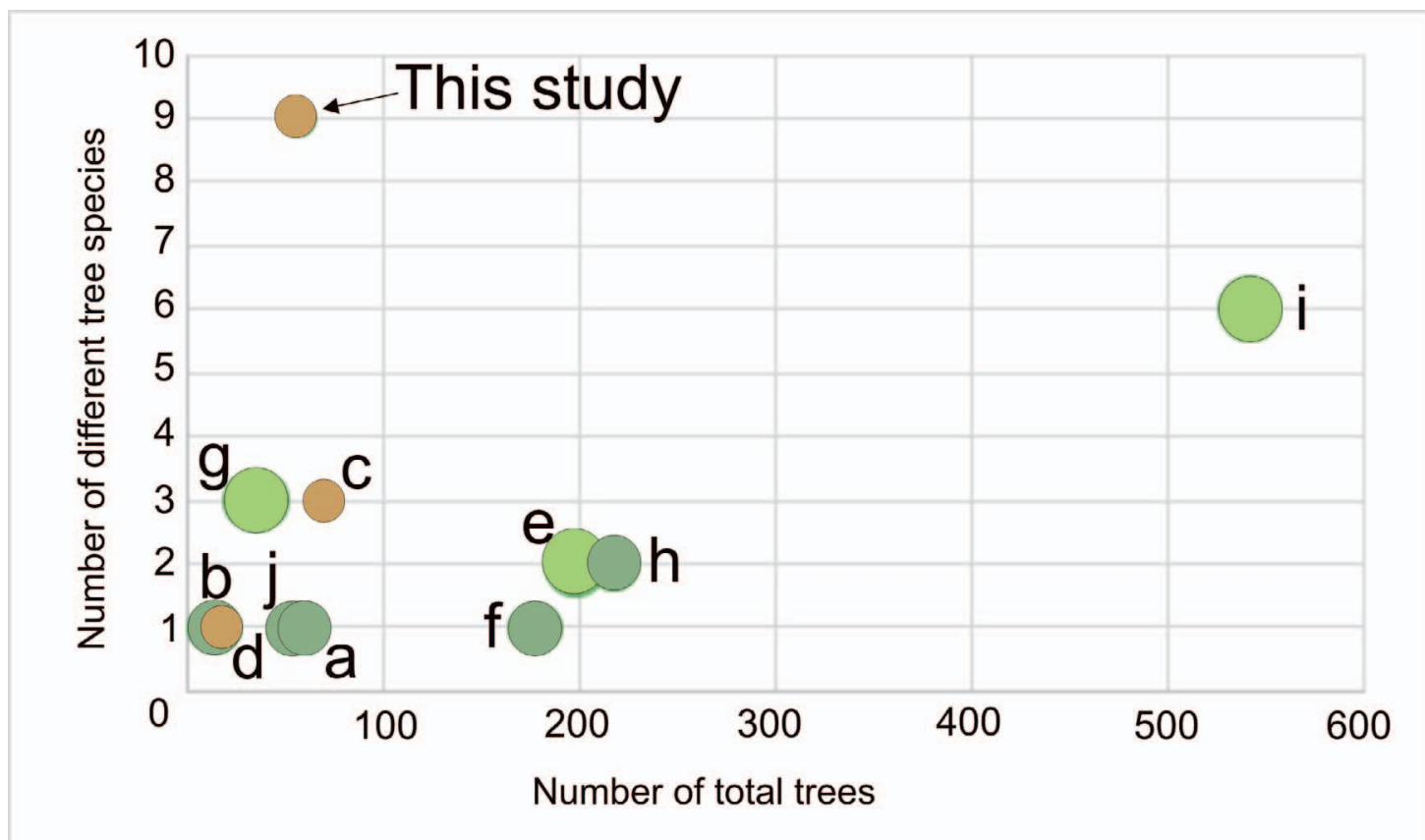

\section{Legend: $\mathrm{B}$ Bradeat as socies}

Coniferous species

Mixed (broadleaf + coniferous)

Figure 6. Relationship between the number of total trees and the number of different species analyzed in previous European flood dendrogeomorphological studies, showing the present study standing out because of the high number of different species used. (a) Zielonka et al. (2008); (b) Ballesteros-Cánovas et al. (2010a); (c) Ballesteros-Cánovas et al. (2010b); (d) Arbellay et al. (2012); (e) RuizVillanueva et al. (2013); (f) Ballesteros-Cánovas et al. (2015b); (g) Ballesteros-Cánovas et al. (2015a); (h) Ballesteros-Cánovas et al. (2015c); (i) Šilhán (2015); (j) Génova et al. (2015a).

species, the scar size, the wound position and the tree age, among other factors. The torrential floods best recorded as dendrochronological evidence are, a priori, extraordinary events of intermediate magnitude (Ruiz-Villanueva et al. 2010). Larger catastrophic events uproot and destroy trees (Génova et al. 2015a), whereas ordinary events of lower magnitude leave little evidence in terms of number and replication to enable their detection. In addition, the close proximity in time of successive events (for example, those occurring in the same year) may mask the evidence corresponding to the earlier events (Ballesteros et al. 2013). Furthermore, the most recent damages (those that happened one or two years ago) are very difficult to date because the tree rings of the callus still cannot be identified properly.

For these reasons, it is essential to interpret all the available evidence together. In this regard, we adopted a new and additional methodological approach of dating decapitations. Decapitations are considered FDE and are more common in larger trees (Stoffel and Bollschweiler, 2008); however, there are currently no systematic studies using decapitated trees to infer dendrogeomorphological events, as stated by Stoffel and Corona (2014). We analyzed decapitations by comparing the ages of the main trunk and replacement branch(es) (Sigafoos, 1964), which indicated that the decapitations may have also occurred in the juvenile stages (Figure 7). The dating of the inner ring of the replacement branches was just an approximation of the decapitation date; the measured inner ring may not always correspond to the first ring and the decapitation may have happened one or several years before. Therefore, it is essential to check the date of the replacement branches with other dated FDEs (for example, suppressions or scars in this study) 

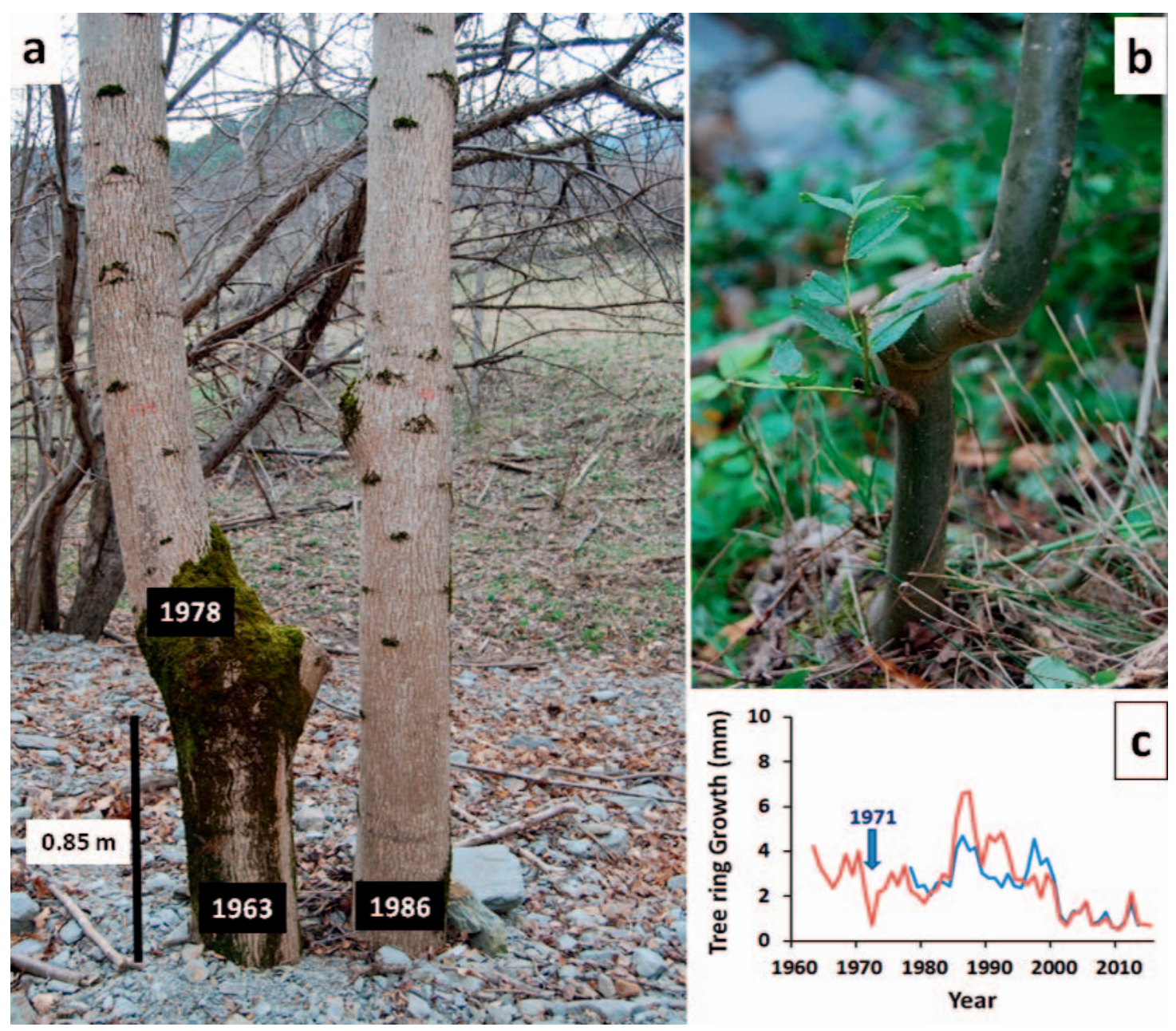

Figure 7. Fraxinus excelsior trees. (a) The PA33 tree (on the left) was decapitated by an event estimated to have occurred in the 1969 1970 Dendrogeomorphological Year, with the PA77 tree (on the right) germinating later. (b) A very young decapitated tree showing a replacement branch. (c) The PA33 tree-ring series; the one corresponding to the main stem (also indicating the detected suppression that was estimated to have occurred in 1971) is shown in red, while the one corresponding to the replacement branch is shown in blue.

and the geomorphological position to better estimate the date of the event that generated the decapitation.

Inferring from the maximum ages estimated in this study, most of the trees were progressively established in the Portainé alluvial cone since the beginning of the 1950s. During previous decades, the west bank of the stream was probably intensely cultivated and when this stopped, the area was colonized by the present vegetation as evidenced by the analysis of orthoimages from different years (Figure 8).

\section{Flood Records from Tree Rings and Documented Events}

This work shows an interesting correlation between the events dated using FDE, eyewitness accounts, and documentary data from the last 60 years. All the documented local events corresponded to the ones indicated by the FDEs, especially for the more recent well-known events.

The present morphology of the debris cone is mainly the result of two peak flows that occurred in 2010, which changed the one produced by the 2008 

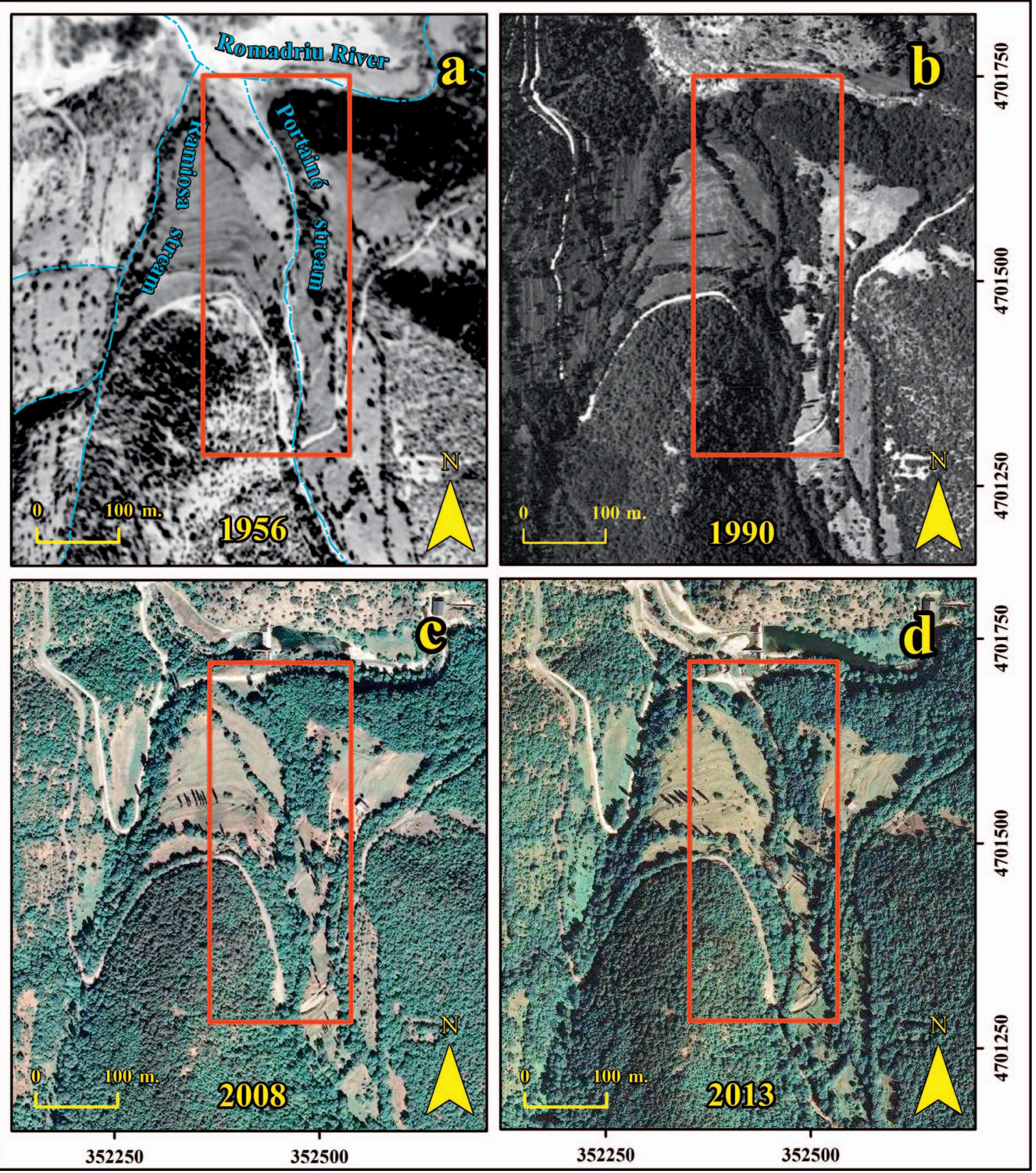

Figure 8. Evolution of the vegetation on the lower stretch of the Portaine stream. The red square corresponds to the study area in Figure 5. In 1956, the debris cone displayed a small amount of vegetation. In 1990, the lower part of the cone was already colonized by trees, with the slopes presenting denser vegetation. By 2008, vegetation was dense all along both streams before the torrential floods. In 2013, the cone appeared as it does now, with clear signs of the torrential flows in the Portainé stream (Orthoimages property of Institut Cartogràfic i Geològic de Catalunya; $\mathrm{CC}$ by 4.0). 
events. This morphology was later slightly modified by the flows occurring in 2011, 2013, 2014 and 2015. The deposits in the alluvial cone originated from dense flows and were reworked by cleaner waters as discharge decreased and later during seasonal ordinary flow regimes.

There is a lot of accurate information on the events that have occurred since 2008. Scarce data exist about the 2006 event, but there are no specific reports about what happened in the Portainé stream before that. The Romadriu basin, including the Portainé area, is remote and sparsely populated, the data about damages being mainly collected from eyewitnesses. For example, the Montenartró Bridge located just on the upper boundary of the study area was destroyed by a flood caused by a severe hail storms at the beginning of the 1960s (Mr. Tachó pers. com.). However, the exact year (between 1960 and 1962) is still unknown (Table 3).

There are more uncertainties regarding major regional events. For the November 1982 event that had widespread effects in the Catalan Pyrenees, Fañanás et al. (2009) consider that a levee was formed in Portainé. However, eyewitnesses and Trapero et al. (2013), who numerically simulated precipitation and found that the higher rainfalls occurred in the Romadriu headwaters, suggested that this event was probably not that severe in the Portaine basin. Despite this, 36 suppressions (but no scars) were dated to 1983 , indicating that some torrential phenomena must have occurred, although there are not enough data to characterize this event. This and other cases illustrate that FDE can be also correlated to some regional floods, as suggested in Table 3. However, this correlation is not unequivocal, as demonstrated by the 2013 event, during which the well-documented regional floods in June did not occur in the Portainé basin, whereas a very local storm in July resulted in a torrential flood that obstructed the access roads to the ski resort. Other FDEs corresponding to 1956-1957, 1964-1965, 1969-1970, 1972-1973 and 1987-1988, before 2006, can only be explained by local events that are probably associated with undocumented orographically-induced summer convective cells. This is the most likely explanation for the event that destroyed the Montenartró Bridge at the beginning of the 1960s. The recent 2008, 2010, 2011, 2013, 2014 and 2015 events also correlate with a localized hydrometeorological occurrence.

In summary, FDE is essential for paleoflood reconstruction. It reflects very well the local flood history and dynamics of this small mountain basin at the DY timescale, which can be different from the more general regional responses to rainfall events.

\section{Frequency of Events versus Human Activities}

Considering the analyzed dendrogeomorphological multi-evidence, vegetation-damaging torrential events also occurred before 2006. Ten events were dated with high reliability, showing an average event recurrence interval of 4.5 years and a significant increase in FDEs since 2006 (Figure 4). This reconstruction of the paleoflood frequency decreases to 3.6 years when other events with less supporting evidence are included. The documentary record shows an event recurrence interval of $c a$. 1 year from 2006 to 2015 (10 torrential events in 9 years, Table 3). With the increase in vegetation occurring on the slopes and riverbanks (Figure 8), one would expect the frequency and intensity of destructive events to fall, but the opposite occurs.

The rainfalls recorded during the events, since 2008 in the region and since 2011 in the basin, were not extraordinary (Palau et al. 2017a, b), even if they presented intense or very intense hourly values. Relatively frequent intense precipitation produces torrential flows with high sediment loads, mainly caused by the new geomorphological conditions (Furdada et al. 2016). All these data indicate that there have been no changes in rainfall, and so this cannot have been the driver of change. This supports the hypothesis that human activities at the ski resort have also affected the hydrologic response of the basin.

\section{CONCLUSIONS}

Damage to the vegetation in the downstream stretch of the Portainé ravine was very well recorded by Flood Dendrogeomorphological Evidence, as were the recent changes in the torrential dynamics. From a methodological point of view, the use of a large number of diverse species and different Flood Dendrogeomorphological Evidence proved to be applicable, efficient and reliable. The highly 
concentrated discharges that recently flowed along the streams and produced more frequent damages to downstream vegetation have coincided with increased human activities in the ski resort, which have altered the surficial hydrology of the catchment. The combination and integration of different data sources produce the best explanation of the changes occurring in the basin.

\section{ACKNOWLEDGMENTS}

This work has been possible thanks to the financial support of the CHARMA and PROMONTEC Projects (MINECO, Ref.: CGL2013-40828R and MINEICO-FEDER, Ref.: CGL2017-84720R) and of an APIF scholarship (UB). We want also thank J. Calvet and G. Khazaradze (UB); C. Fañanás (Dpt. d'Agricultura, Ramaderia, Pesca i Alimentació, Generalitat de Catalunya); the FGC and ICGC personnel, the Arxiu Comarcal del Pallars Sobirà personnel; Ll. Pla (MeteoPirineu), M. Barriendos (UB) manager of the PREDIFLOOD database; C. Llasat (UB) manager of the GAMA floods database; and the hydroelectric company OPICE S.A.

\section{REFERENCES CITED}

ABC Library [on line], 1974. Madrid: Diario ABC, S.L. [consulted 07/02/2017]; http://hemeroteca.abc.es/ nav/Navigate.exe/hemeroteca/madrid/abc/1974/09/20/043.html

Alestalo, J., 1971. Dendrochronological interpretation of geomorphic processes. Fennia 105:1-140.

Arbellay, E., P. Fonti, and M. Stoffel, 2012. Duration and extension of anatomical changes in wood structure after cambial injury. Journal of Experimental Botany 63(8):3271-3277.

Arbellay, E., M. Stoffel, and M. Bollschweiler, 2010. Dendrogeomorphic reconstruction of past debris-flow activity using injured broad-leaved trees. Earth Surface Processes and Landforms 35(4):399-406.

Arxiu Comarcal del Pallars Sobirà [on line], 2015. Barcelona: Generalitat de Catalunya, Dep. Cultura, Xarxa d'Arxius Comarcals [consulted 09/05/2017]; http://arxiusenlinia.cultura.gencat.cat/ArxiusEnLinia/

Astrade, L., and Y. Bégin, 1997. Tree-ring response of Populus tremula L. and Quercus robur L. to recent spring floods of the Saône River, France. Ecoscience 4(2):232-239.

Balasch, C., J. Becat, C. M. Marugan, A. Nadal, V. Rapalino, and R. Remacha, 2008. Les riuades del segle XX al Pallars Sobirà: 1907, 1937 i 1982. Colección: Arxius y societat: Quaderns de divulgació històrica $\mathrm{n}^{\circ}$ 2, Departament de Cultura i Mitjans de Comunicació, Generalitat de Catalunya. Barcelona; 240 pp.
Ballesteros, J. A., M. Sánchez-Silva, J. M. Bodoque and A. DíezHerrero, 2013. An integrated approach to flood risk management: A case study of Navaluenga (Central Spain). Water Resources Management 27(8):3051-3069.

Ballesteros-Cánovas, J. A., B. Czajka, K. Janecka, M. Lempa, R. J. Kaczka, and M. Stoffel, 2015c. Flash floods in the Tatra Mountain streams: Frequency and triggers. Science of the Total Environment 511:639-648.

Ballesteros-Cánovas, J. A., C. Rodríguez-Morata, V. GarófanoGómez, J. M. Rubiales, R. Sánchez-Salguero, and M. Stoffel, 2015b. Unravelling past flash flood activity in a forested mountain catchment of the Spanish Central System. Journal of Hydrology 529:468-479.

Ballesteros-Cánovas, J. A., M. Stoffel, C. Corona, K. Schraml, A. Gobiet, S. Tani, F. Sinabell, S. Fuchs, and R. Kaitna, 2016. Debris-flow risk analysis in a managed torrent based on a stochastic life-cycle performance. Science of the Total Environment 557:142-153.

Ballesteros-Cánovas, J. A., M. Stoffel, S. St. George, and K. Hirschboeck, 2015a. A review of flood records from tree rings. Progress in Physical Geography 29(6):1-23.

Benito, G., and A. Díez-Herrero, 2015. Palaeoflood hydrology: Reconstructing rare events and extreme flood discharges. In Hydro-Meteorological Hazards, Risks, and Disasters, edited by Shroder, J. F., P. Paron, and G. Di Baldassarre, pp. 65-104. Elsevier, Amsterdam, The Netherlands.

Bollschweiler, M., M. Stoffel, and R. Schlaeppy, 2011. Debrisflood reconstruction in a pre-alpine catchment in Switzerland based on tree-ring records of coniferous and broadleaved trees. Geografiska Annaler: Series A, Physical Geography 93(1):1-15.

Brown, P. M., and C. H. Sieg, 1996. Fire history in interior ponderosa pine communities of the Black Hills, South Dakota, USA. International Journal of Wildland Fire 6(3):97-105.

Büntgen, U., P. J. Krusic, A. Verstege, G. Sangüesa Barreda, S. Wagner, J. J. Camarero, F. C. Ljungqvist, E. Zorita, C. Oppenheimer, O. Konter, W. Tegel, H. Gartner, P. Cherubini, F. Reinig, and J. Esper, 2017. New tree-ring evidence from the Pyrenees reveals western Mediterranean climate variability since medieval times. Journal of Climate 30(14):52955318.

Cook, E., and L. Kairiukstis, 1990. Methods of Dendrochronology. Applications in the Environmental Sciences. Kluwer Academic Publishers, Dordrecht.

Díez-Herrero, A., J. A. Ballesteros, V. Ruiz-Villanueva, and J. M. Bodoque, 2013b. A review of dendrogeomorphological research applied to flood risk analysis in Spain. Geomorphology 196:211-220.

Díez-Herrero, A., J. A. Ballesteros-Cánovas, J. M. Bodoque, and V. Ruiz-Villanueva, 2013a. A new methodological protocol for the use of dendrogeomorphological data in flood risk analysis. Hydrology Research 44(2):234-247.

El Mundo Library [on line], 1997. Madrid: Unidad Editorial Información General, S.L.U. [consulted 07-28/03/2017]; www.elmundo.es/elmundo/1997/diciembre/19/nacional/ cenegal.html

Fañanás, C., N. Aguilar Marín, C. Raïmat Quintana, and R. Luis Fonseca, 2009. Corrección hidrológica en el barranco de Portainé. In VII Simposio Nacional sobre Taludes y Laderas 
Inestables, edited by E. Alonso, J. Corominas and M. Hürlimann, M., pp. 999-1011. CIMNE, Barcelona.

FGC and ICGC, 2015. Seguiment geològic i geotècnic de la carretera d'accés a Port Ainé, 24 d'agost de 2015, AP-079/15.

Furdada, G., M. Génova, M. Guinau, A. Victoriano, G. Khazaradze, A. Díez-Herrero, and J. Calvet, 2016. Las avenidas torrenciales de los barrancos de Portainé, Reguerals y Ramiosa (Pirineo Central): Evolución de las cuencas y dinámica torrencial. In Comprendiendo El Relieve: Del Pasado Al Futuro, edited by J. J. Durán Valsero, M. Montes Santiago, A. Robador Moreno, and A. Salazar Rincón, pp. 315-322. Instituto Geológico y Minero de España, Madrid.

García-Oteyza, J., M. Génova, J. Calvet, G. Furdada, M. Guinau and A. Díez-Herrero, 2015. Datación de avenidas torrenciales y flujos de derrubios mediante metodologías dendrogeomorfológicas (barranco de Portainé, Lleida, España). Revista Ecosistemas 24(2):43-50.

Génova, M., J. García-Oteyza, J. Calvet, G. Furdada, M. Guinau, and A. Díez-Herrero, 2015b. Flash floods and debris flows in Portainé stream (Lleida, Spain) dated through dendrogeomorphological methodologies. In Tree Rings in Archaeology, Climatology and Ecology (TRACE 2015), Abstract volume, P18, edited by Hevia, A. and R. Sánchez-Salguero. Universidad Pablo de Olavide and Association for Tree-Ring Research, 20-23 May 2015, Sevilla, Spain.

Génova, M., P. Máyer, J. A. Ballesteros-Cánovas, J. M. Rubiales, M.A. Saz, and A. Díez-Herrero, 2015a. Multidisciplinary study of flash floods in the Caldera de Taburiente National Park (Canary Islands, Spain). Catena 131:2234.

Grissino-Mayer, H. D., 1993. An updated list of species used in tree-ring research. Tree-Ring Research 53:17-43.

Grissino-Mayer, H. D., 2001. Evaluating crossdating accuracy: A manual and tutorial for the computer program COFECHA. Tree-Ring Research 57(2):205-221.

Harrison, S. S., and J. R. Reid, 1967. A flood-frequency graph based on tree-scar data. Proceedings of the North Dakota Academy of Science 21:23-33.

Hartevelt, J. J. A., L.-U. de Sitter, H. J. Zwart, and J. F. Savage, 1969. Geological Map of Central Pyrenees. Sheet 10. Geological Institute, Leiden University, Netherlands.

Holmes, R. L., 1999. Dendrochronological Program Library (DPL). User's Manual. Laboratory of Tree-Ring Research, University of Arizona. Tucson.

ICC and Meteocat., 2008. Atles Climátic de Catalunya 19611990. Institut Cartogràfic de Catalunya and Servei Meteorològic de Catalunya, Barcelona, Spain.

IGC, 2008. Nota tècnica sobre la visita al barranc de Portainé i al barranc des Caners els dies 1 i 2 d'octubre de 2008 en motiu de la torrentada ocorreguda la matinada del dia 12 de Setembre de 2008, AP-187/08 Report. Institut Geològic de Catalunya, Barcelona, Spain; $15 \mathrm{pp}$

IGC, 2010a. Estudi de la torrentada de la nit del dia 11 al 12 de Setembre de 2008 al barranc de Portainé (Pallars Sobirà), AP-019/10 Report. Institut Geològic de Catalunya, Barcelona, Spain; 169 pp.

IGC, 2010b. Nota de la visita al barranc de Portainé (Pallars Sobirà) arran del episodi de pluges dels dies 22 i 23 de Juliol de 2010, AP-046/10 Report. Institut Geològic de Catalunya, Barcelona, Spain; 40 pp.

IGC, 2011. Nota de la visita al barranc de Portainé (Pallars Sobirà) arran de l'episodi de pluges del dia 5 d'agost de 2011, AP-054/11 Report. Institut Geològic de Catalunya, Barcelona, Spain; 62 pp.

IGC, 2013a. Avaluació de la dinàmica torrencial del torrent de Portainé, AP-035/13 Report. Institut Geològic de Catalunya, Barcelona, Spain.

IGC, 2013b. Nota de la visita al barranc de Portainé (Pallars Sobirà) arran de l'episodi de pluges del dia 23 de Juliol de 2013, AP-091/13 Report. Institut Geològic de Catalunya, Barcelona, Spain; 49 pp.

IGC, GEOCAT and FGC, 2013. Informe de visita de terreny de les esllavissades i barrancades a la carretera d'accés a Portainé a Juliol de 2013, AP-057/13 Report. Institut Geològic de Catalunya, Gestió de Projectes S.A. and Ferrocarrils de la Generalitat de Catalunya, Barcelona, Spain; 45 pp.

Khazaradze, G., M. Guinau, J. Calvet, G. Furdada, A. Victoriano, and M. Génova, 2016. Debris flow cartography using differential GNSS and Theodolite measurements. Geophysical Research Abstracts 18, EGU2016-9696. https://meetingorganizer.copernicus.org/EGU2016/EGU20169696.pdf.

Kochel, R. C., B. R. Hayes, J. Muhlbauer, Z. Hancock, and D. Rockwell, 2016. Geomorphic response to catastrophic flooding in north-central Pennsylvania from Tropical Storm Lee (September 2011): Intersection of fluvial disequilibrium and the legacy of logging. Geosphere 12(1):305-345.

La Vanguardia Library [on line], 1982. Barcelona: La Vanguardia Ediciones S.L. [consulted 07-28/03/2017]; http://hemeroteca. lavanguardia.com/preview/1982/11/15/pagina-4/32956298/ pdf.html?search=inundaciones.

Meteorological Service of Catalonia, 2017 (update). Climatologia. Serveis i dades climàtiques. Sèries climàtiques històriques [on line]. Barcelona: Servei Meteorològic de Catalunya, Generalitat de Catalunya. Updated 07/03/2017 [consulted 15/03/2017]; http://static-m.meteo.cat/wordpressweb/wpcontent/uploads/2017/06/19093925/horrm00000575d.txt.

Ortuño, M., M. Guinau, J. Calvet, G. Furdada, J. Bordonau, A. Ruiz, and M. Camafort, 2017. Potential of airborne LiDAR data analysis to detect subtle landforms of slope failure: The example of Portainé, Central Pyrenees. Geomorphology 295:364-382.

Palau, R. M., M. Hürlimann, M. Berenguer, and J. Pinyol, 2017b. Analysis of the rainfall conditions inducing torrential activity in the Portainé catchment (Eastern Pyrenees, Spain). Geophysical Research Abstracts Vol. 19, EGU2017-12494. http://meetingorganizer.copernicus.org/EGU2017/EGU201712494.pdf

Palau, R. M., M. Hürlimann, J. Pinyol, J. Moya, A. Victoriano, M. Génova, and C., Puig, 2017a. Recent debris-flows in the Portainé catchment (Eastern Pyrenees, Spain). Analysis of monitoring and field data focusing on the 2015 event. Landslides 14(3):1161-1170.

Pinyol, J., M. Hürlimann, G. Furdada, M. Moysset, R. M. Palau, A. Victoriano, M. González, J. Moya, M. Guinau, C. Raïmat, and C. Fañanás, 2017. El barranco de Portainé (Pirineo 
Central): Un laboratorio in situ completo para el estudio de la actividad torrencial. In IX Simposio Nacional sobre Taludes y Laderas Inestables, edited by Alonso, E., J. Corominas, and M. Hürlimann, pp. 1165-1176. CIMNE, Barcelona.

Protección Civil, Catálogo Nacional de inundaciones Históricas, actualización [on line], 2014 (update). Cuenca del Ebro. Estudio de Inundaciones históricas. Mapa de Riesgos Potenciales. CTEI 1985 [on line] Madrid: Ministerio del Interior. Updated 2014 [consulted 07 February 2017]. http://www.proteccioncivil.es/catalogo/naturales/cnih/ cnih2014/PDF/B6/Documenta2/CTEI_EBRO.pdf.

Rinn, F., 2003. TSAP-Win: Time Series Analysis and Presentation for Dendrochronology and Related Applications, Version 0.53: User Reference. RinnTech, Heidelberg.

Ruiz-Villanueva, V., A. Díez-Herrero, J. M. Bodoque, J. A. Ballesteros Cánovas, and M. Stoffel, 2013. Characterisation of flash floods in small ungauged mountain basins of Central Spain using an integrated approach. Catena 110: $32-43$.

Ruiz-Villanueva, V., A. Díz-Herrero, M. Stoffel, M. Bollschweiler, J. M. Bodoque, and J. A. Ballesteros, 2010. Dendrogeomorphic analysis of flash floods in a small ungauged mountain catchment (Central Spain). Geomorphology 118(3):383-392.

Schweingrüber, F. H., 1990. Anatomy of European Woods. Paul Haupt Verlag, Bern.

Shroder, J. F., 1980. Dendrogeomorphology: Review and new techniques of tree-ring dating. Progress in Physical Geography 4(2):161-188.

Sigafoos, R. S., 1964. Botanical Evidence of Floods and FloodPlain Deposition. Geol. Surv. Prof. Paper (U.S.) 485-A; $35 \mathrm{pp}$.

Šilhán, K., 2015. Frequency, predisposition, and triggers of floods in flysch Carpathians: Regional study using dendrogeomorphic methods. Geomorphology 234:243-253.
St. George, S., and E. Nielsen, 2003. Paleofloods records for the Red River, Manitoba, Canada, derived from anatomical treering signatures. The Holocene 13(4):547-555.

Stoffel, M., and M. Bollschweiler, 2008. Tree-ring analysis in natural hazards research? An overview. Natural Hazards and Earth System Science 8(2):187-202.

Stoffel, M., M. Bollschweiler, D. R. Butler, and B. H. Luckman, 2010. Tree Rings and Natural Hazards: A State of the Art. Springer, Heidelberg, New York.

Stoffel, M. and C. Corona, 2014. Dendroecological dating of geomorphic disturbance in trees. Tree-Ring Research 70(1):3-20.

Stoffel, M., B. Wyżga, and R. A. Marston, 2016. Floods in mountain environments: A synthesis. Geomorphology 272:1-9.

Trapero, L., J. Bech, F. Duffourg, P. Esteban, and J. Lorente, 2013. Mesoscale numerical analysis of the historical November 1982 heavy precipitation event over Andorra (Eastern Pyrenees). Natural Hazards and Earth System Sciences 13(11):29692990.

Victoriano, A., A. Díez-Herrero, M. Génova, M. Guinau, G. Furdada, G. Khazaradze, and J. Calvet, 2018. Four-topic correlation between flood dendrogeomorphological evidence and hydraulic parameters (the Portainé stream, Iberian Peninsula). Catena 162:216-229.

Victoriano, A., M. Guinau, G. Furdada, J. Calvet, M. Cabré, and M. Moysset, 2016. Aplicación de datos LiDAR en el estudio de la dinámica torrencial y evolución de los barrancos de Portainé y Reguerals (Pirineos Centrales). In Comprendiendo El Relieve: Del Pasado Al Futuro, edited by Durán Valsero, J. J., M. Montes Santiago, A. R. Moreno, and A. S. Rincón, pp. 447-455. Instituto Geológico y Minero de España, Madrid.

Zielonka, T., J. Holeksa, and S. Ciapała, 2008. A reconstruction of flood events using scarred trees in the Tatra Mountains, Poland. Dendrochronologia 26(3):173-183.

Received 8 June 2017; accepted 10 March 2018. 